\title{
The Debate on the Concept of Value: Interpretations from the Perspective of Economics and Social Anthropology
}

\author{
Juan José García del Hoyo \\ Professor of Econometrics and Quantitative Methods, University of Huelva (Spain); Email: hoyo@uhu.es
}

Celeste Jiménez de Madariaga

Professor of Social Anthropology, University of Huelva (Spain); Email: celeste@uhu.es

\section{Doi:10.5901/mjss.2016.v7n2p11}

\begin{abstract}
The objective of this paper intend to compare the different interpretations on the theory of value, taking into account the prior background, be it from an economic or an anthropological perspective. In this case, we used the literature review method as an important part of the research, its purpose is to provide a justification of work conducted. For this, we review of the answers that have been given about the notion of value from economics and anthropology. In this review, the greater difficulty has been, indeed, the historical separation between disciplines that frequently have developed their theoretical conceptualizations about economic fact separately, while the cooperation attempts have had to overcome important methodological and formal differences. Although methodologies close to the anthropological thought and practice underlay classical economics because they use arguments based on institutions and cultural diversity, the possible combination between both sciences did not materialise due to the success of neoclassical formalism. The only exceptions arise in schools of economic thought which are away from the mainstream. In this paper, we use the theory of value to demonstrate this process.
\end{abstract}

Keywords: value theory, economics, social anthropology, institutions, culture.

\section{Introduction}

In this paper we intend to compare the different interpretations on the theory of value, taking into account the prior background, be it from an economic or an anthropological perspective, in order to show that the visions complement and enrich each other. We face the difficult challenge of defining "value", a term that has a different meaning in each social science.

Practically ever since both sciences became consolidated, there has been a certain incompatibility and mutual lack of knowledge between anthropology and economics, possibly due to the enormous methodological differences between them, for example, the juxtaposition between qualitative and quantitative aspects. Even though anthropology has seen the emergence of a specific branch that focuses on the analysis of economic problems - economic anthropology economics has ignored or bypassed the contributions made by this closely related specialty area. Knight (1941), the founder of the Chicago School, came face to face with Herskovits (1952), who had coined the term "economic anthropology". He made relatively harsh statements and even argued that economics is the only social science to employ a deductive hypothetical method.

To do it, first, we make a review of the contributions about the concept of value from the mainstream of economics. Then, we present the main convergences which have occurred with social anthropology on this crucial item to build economics. Finally, we verify that, despite what is generally believed, there is sufficient evidence to confirm the existence of a mutual influence and, above all, to support that it has a growing trend.

Given our conviction that there really are theoretical and methodological links between the approaches of economists and anthropologists, our goal is to provide a joint review of the responses given by both disciplines on one of the main problems in the economic thought: the value theory. This paper aims to show how both scientific fields complement each other and how there is the need for a multidisciplinary analysis of this subject.

\section{Use Value and Exchange Value}

The theory of value consists in analysing the causes that enable a commodity to have a use value, while the theory of 
exchange value or market value consists in the analysis of price formation mechanisms. The utility or "use value" of a commodity is nothing more than the satisfaction or pleasure a person derives from owning it, while the "exchange value" can be identified via the price of things in money or in units of other goods. From the first philosophical ideas that could be interpreted as the origin of economics, the choice between use value and exchange value arises. Aristotle, while recognising the role played by the use value, only developed an analysis of the current price, based on the cost of production. Augustine of Hippo added the subjective concept of needs. On the other hand, Albert Magnus provided a clear definition of the exchange value as the relative price, and he expressively introduced the equivalence between the just price and its settlement in costs and labour, thus consolidating the difference between the use value, and the exchange value, and the different interpretations on the former value: on the one hand the subjectivist interpretation, based on satisfying human needs, and on the other hand the objectivist interpretation, based on the cost of production and labour.

\subsection{The view of the Classical economics}

Without underestimating previous contributions made by scholastic or economists of the seventeenth and early eighteenth centuries, the fact is that the consolidation of economics as a science is often in Adam Smith's work. Therefore, we began our review precisely with his contemporary authors such as Richard Cantillon, as well as with the "classical school of economics". As we shall see, it seems to use an objectivist interpretation of value and continues with the marginalism of the late XIX century, where the subjective interpretation of the concept of value is resumed. Cantillon distinguished two components in the exchange value, on the one hand the so-called «price or intrinsic value», which is related to the just price, and on the other hand, the "market price", which is determined by the needs of individuals. The former «is the measure of the quantity of Land and of Labour entering into its production», but also «that will depend on the Humours and Fancies of men and on their consumption» (1959 [1775], 38). However, Petty another predecessor of the classical branch in some issues, such as labour division, and above all, the theory of value, which is based on the land and labour that goes into a product.

Meanwhile, Adam Smith differentiated "use value" from "exchange value", although he mainly focused on the analysis of the latter, stating, that «the value of any commodity, therefore, to the person who possesses it ... is equal to the quantity of labour which it enables him to purchase or command» (1904 [1776], 32). But his goal was to establish a stable and homogenous counting unit, which would overcome fluctuations and depreciations in currency in a bimetallism context. His conception of the natural price is identical to Cantillon's long-term concept that was in opposition to the shortterm market price, yet fluctuated according to the market. It adjusts to the market by means of an automatic mechanism, i.e. the market has an impact on the production by means of the action performed by an «invisible hand», which assigns resources efficiently. However, by backing a theory of prices based on the cost of production, he overlooked the fact that the costs of production are also themselves prices that have been determined in the markets of productive factors, thus leading to a circular argument that invalidates his interpretation.

David Ricardo also presented a theory of prices based on the costs of production. He understood it to be a necessary condition for something to have value, but once this condition has been met, the value is defined according to two sources: scarcity and the quantity of work needed to obtain it. He admits that the exchange value should also include capital profit, always by means of the value given to the work necessary for its accumulation.

Malthus made some original contributions, by establishing three categories: firstly, the value in the use, known as «intrinsic utility», secondly, the nominal exchange value, expressed in precious metals, and lastly, the intrinsic exchange value. This value becomes the equivalent of the result from «the state of the supply compared with the demand, and ordinarily by the elementary cost of production» $(1836,60)$, which may become independent from the cost of production in «a class of commodities of greatest extent», thus rejecting the existence of an objective measurement of the value in exchange (1836 [1820], 70).

J.B. Say links the theory of value to the theory of distribution by means of paying for the triad of factors or production costs: land rent, salaries and interests. His contributions oppose any objective calculation that does not take utility into account, thus avoiding making a difference between use value and exchange value. However, he does link both concepts, given that the second establishes «le prix des produits s'établissait en chaque endroit aux taux où les portent leurs frais de production, pour vu que l'utilité qu'on leur donné fasse naître le désir de les acquérin» (J.B. Say, 1826, 169). Say paves the way towards the modern economic theory by underpinning the concept of value in two different phenomena: in the commodity's utility seen from the perspective of demand, and in the production costs seen from the perspective of supply. Furthermore, unlike Smith, Ricardo and Malthus, he understands that value, i.e. utility, sets the prices, and not the other way around, although he does uphold that prices and costs would have to level out in the long term. 
J.S. Mill was convinced that everything had been said about the theory of value ${ }^{1}$. He distinguished between the exchange value, otherwise known as «general power of purchasing», and the current price, «value of thing in relation to money» (1870 [1848], 538). Nevertheless, his main contribution was found in the way he interrelated them, by concluding that the former is the top limit of the latter. His theory on prices was practically identical to Ricardo's theory, as he considered that commodities have a value of natural exchange, which are determined by the production costs and a price determined by supply and demand, which tends to get closer to the natural price in the long term.

$\mathrm{K}$. Marx set the use value and the ability to satisfy human needs as preconditions for commodities to reach a price or exchange value, irrespective of whether «they spring from the stomach or from fancy» (2007 [1867], 41). This placed him in a rather more subjectivist position than Ricardo, Smith or Malthus, but he was just as inconclusive. His position was quite clear, as he stated that «Lastly, nothing can have value, without being an object of utility. If the thing is useless, so is the labour contained in it; the labour does not count as labour, and therefore creates no value» (2007 [1867], 48). From this point onwards, Marx left aside subjectivism and focused on developing an explicative theory on prices achieved through integrated labour, «the amount of work socially needed», referring to the average amount of hours required for the production of the object, which could change over time due to the rise of technology or the capacity-building of workers. He maintained that capitalists take ownership of part of the surplus value that belongs to the worker, because capitalists do not pay workers for the entire value of their performed work; part of the generated wealth is appropriated by the business owner, while the worker only receives a subsistence salary.

The cycle of classical economics reached an end with Marx and the body of doctrines became the foundation of current economics. However, classical economists made practically no proposals when it comes to the theory of value, because what they really developed was a theory of prices, which are determined by costs of production in the long term. But given that costs of these factors are also prices themselves, they entered a vicious circle that was hard to get out of.

\subsection{Marginalist revolution and neoclassical value theory}

The concept of marginal utility did not spread among economists until real research had taken off among academics, who were interested in the general aspects of economics (Stigler, 1972, 574). W. S. Jevons, C. Menger and L. Walras are known for having developed this science. The goal of economics is reduced to «is to maximise happiness by purchasing pleasure, as it were, at the lowest cost of pain» (Jevons, 1871, 27). Utility, in its quantitative magnitude, is the ability that an object, i.e. the commodity, has to generate pleasure or hinder discomfort. J.S. Mill, based on the ideas developed by Bentham, disseminated this theory. They supported the theory of value in the concept of marginal utility: the more units of commodities an individual owns, the lower the utility attributed to them, as long as the units are equal in terms of quantity and quality. The value of the commodity would be given according to the utility of the last need that is satisfied, and therefore the marginal utility would decrease the more units are owned. Jevons and Walras used introspective cardinalism (Majumdar, 1958), a cardinal scale of preferences by means of a differential calculation, while Menger believed in an ordinal scale and gave a more general and precise interpretation. None of them used the term "marginal utility". Jevons made a distinction between «total utility», «degree of utility», and «final degree of utility», which is the degree of utility found in the last portion of an infinitely small amount from the commodity. Meanwhile, Walras used the term rareté or «l'intensité du dernier besoin qui peut être satisfait» (1977 [1874], 119) whereas Menger distinguished between different levels of need for the same commodity, and each level serves a different degree of utility, stating that «the value of a particular good... is thus for him equal to the importance of the least important of the satisfactions assured by the whole available quantity and achieved with any equal portion» (2007 [1871], 139). Marginalists clearly distinguish between the terms "use value" and "exchange value", thus demonstrating the ambiguity of this terminology, and for this reason the former was replaced by the term "utility" and the latter by "price". Moreover, both Walras and Menger categorically break away from the classical economists after rejecting that production costs can determine prices. In the first case, prices are specified in the market according to their utility, determining the demand, and according to their relative scarcity, determining the supply, and not according to the costs of productive services, which are actually determined in the market of factors according to their own available demand and supply. However, Menger introduced a subtle yet essential difference when demonstrating that both processes are not simultaneous, but rather reinforced by expectations instead. Prices of commodities of a lower order are determined according to market conditions, while prices of commodities of a higher order, i.e. productive factors, materialise in the future; that is to say that the actual cost of productive factors is the result of the expected prices of commodities they contribute to produce. Therefore, Menger, and

1 «Happily, there is nothing in the laws of value which remains for the present or any future writer to clear up: the theory of the subject is complete» (Mill, 1870 [1848], p. 536-537). 
to a lesser extent Walras, clearly perceived that this mechanism is the opposite to the one suggested by the classical theory of prices determined by the cost of production, and thus invalidate the theory of prices in Classical Economy. Instead of following an objective relation regarding the cost of production, they believe in a subjective relation between commodities and individual states of awareness, in such a way that, given the fact that the human fundamental awareness instincts would remain the same, «the principle would hold for any type of economic society» (Dobb, 1937, 26).

Marshall was perhaps the economist who most influenced the dissemination of marginalist theory of value. According to Marshall, economics was still a science that studies the useful and the scarce, the relative scarcity being confined to commodities that can be consumed. He used the theory of marginal utility in order to develop the demand curve, and the functions of costs for the offer curve, thus laying the foundations for conventional microeconomics by presenting the principle of decreasing marginal utility. Yet while claiming that price was determined by demand in the short term, he maintained, in his quest to "complete" the economic theory put forward by the classical economists, that prices were determined by the costs of production in the long term, and by the combination of supply in demand in the medium term, grounded in the costs and in marginal utility. Like Bentham, he considered that utility curves were additive and could be compared through the use of money. Thus the price of a commodity would be a measure of its marginal utility, and interpersonal comparisons would be enabled. Neoclassical economics as defended by Marshall was known simply as "Economics", a name he gave the science to differentiate it from the classical economists and Marxists' "Political Economy". Economics made the same mistake as the classical economists, abandoned the course set by Menger and Walras and defended the supply curve once again over production costs. But following an analysis of consumer surplus, Marshall laid the foundations for the neoclassical theory of welfare, which would be formally developed by his disciple Pigou (1912). Pigou justified redistributive policies based on the implementation of progressive taxation in order to compensate external diseconomies that were visible in the divergence of private and social costs, and to justify state intervention ${ }^{2}$. In turn, he considered that marginal utilities were additive, as they were comparable and measurable, and he believed that social welfare could be defined as the algebraic sum of different individual utilities, and distributive equity therefore implied maximisation of social utility. Pareto (1971) [1906] followed on the line of the general balance of Walras and developed a consumer theory by trying to replace marginal utility with the concept of preferences. He reused the indifference curve tool that Edgeworth $(1881,21-22)^{3}$ had introduced, and proposed leaving behind the measurement of utility by means of cardinal scales of utility functions, and centring instead on ordinal preferences, in line with Menger ${ }^{4}$. Moreover, he criticised the classical theory of value and the identification between production cost and price or value, given that this was determined by «the opposition between the tastes and the obstacles» $(1971,232)$, that is to say, utility (ophelimite, in his terminology) and costs. In his development of the general balance, which formalises Smith's notion of the «invisible hand», he justified the inequality in the distribution of income, by staunchly defending the market mechanism, which could lead to a social optimum, thus advocating for state non-interference in the economy. Yet Pareto follows Walras' line of thought and this also leads him to admit that economic relations are simultaneous, thus ultimately defending that supply plays a determining role through production costs.

The Austrian school, of which Menger was the precursor, maintained this reasoning up to a certain extent. Von Mises interpreted utility as the «importance attached to a thing on account of the belief that it can remove uneasiness» (1963 [1949], 120), relating it to the «value of subjective use», while the «value of objective use» is the existing relation between an object and the effects it produces. He continued isolating the concept of utility from other considerations and affirmed that «Neither is value (subjectively used) in words and doctrines. It reflected in human conduct» (Mises, 1963 [1949], 96).

Hicks and Allen (1934) developed the consumer theory once again. In introspective ordinalism, there was no need to consider utility to be measurable, but rather a mere ordinal scale of preferences, decreasing demand curves and doing without Marshall's addition of utility curves, which would only be measurable in an ordinal manner. This is because it is based on two non-universal psychological assumptions: individuals' behaviour by introspection and their pursuit of

${ }^{2}$ Although his ideas were soon challenged by economists from the Chicago school, such as Frank Knight, who denied the role of the state in redistribution; there were no mistakes in the market, but rather an inadequacy in property rights. Coase also backed this line of thought. (1960).

${ }^{3}$ His work links up with Bentham's hedonist calculation, which now builds on the differential calculation. "the conception of Man as a pleasure machine may justify and facilitate the employment of mechanical terms and Mathematical reasoning in social science» (Edgeworth, 1881, 15).

${ }_{4}^{4}$ Pareto (1971) [1906] and Fisher (2007) [1892] start to strip microeconomics from any hint of utilitarianism and set a trend; the indifference curve tool allows for a consumer theory that is exclusively based on preference scales, with no need to justify these through an utility surface. 
maximisation. Samuelson (1938) had already published the rudimentary principles of what would become a new paradigm: behaviourist ordinalism. This was achieved by means of the revealed preferences theory and was additionally based on fewer assumptions. It was based on the irrefutable principles that justify the neoclassical consumer theory. Subsequently, it is not the individual preferences that are known, but rather the different choices that the individual has made. That is to say, the notion of utility is considered to be inadequate for a scientific theory because it is empirically impossible to verify (Samuelson, 1938, 61). The same happened with theories based on the marginal rate of substitution, so he suggested developing a new theory that would build on observable behaviour. Yet, despite the mathematical formalism and the ambitious goal «with such theorems, there is nothing the practising economist can take away with him to help him come to grips with the complexity of the real world» (Mishan, 1961, 1) to the extent that both theories, together with Debreu's (1959) theory of behaviour, emerge in an effort to purge all irrelevant assumptions and «it now stands as an example of how to extract the minimum of results from the minimum of assumptions» (Lancaster, 1966, 132).

\section{Institutionalism and Neo-institutionalism vs. Social Anthropology}

The so-called institutional economics was founded by Thorstein Veblen, John Commons and Wesley Mitchell, among others, in North America and was the predominant school up until the introduction of Keynesian theories and the development of econometrics in the 1940s. According to these authors, prices are social conventions, which are reinforced by habits and included as an integral part of specific institutions that partly depend on ideas. For this reason, a theory on prices should also include a theory on ideas, on expectations, on customs and on institutions, so as to be able to properly explain the mechanism used by individuals to calculate or to shape their expectations for the future. Veblen vehemently criticised neoclassical contributions, and accused the neoclassical economists of having Bentham and Mill as precursors due to the hedonist calculation of utilities, which he attributed to the mistaken conceptualisation of economic conduct. He criticised it by stating that «marginal-utility theory... it offers no theory of a movement of any kind, being occupied with the adjustment of values to a given situation» (Veblen, 1909, 620), and that it did not integrate relevant aspects such as the rise of technology, the development of corporate culture, or rules and institutions that regulate economic activity. Veblen was influenced by anthropologists such as Morgan (1877), and thus considered cultural elements (institutions, human relations, customs and habits) to be relevant to the theory of value, which in turn is only part of the setting in which action develops according o neoclassical economics 5 .

Mitchell took a similar stance, suggesting that different sciences such as ethnology and anthropology and the impact they were having on human nature should be observed (Mitchell, 1914, 3). As we can see, institutional economics and its successor, neo-institutional economics, along with anthropology came together in their common interest for collective action, the role of technology and social change. Many of the institutionalists' principles are shared by economic anthropologists, except for the more extreme formalists (Burling, 1962; Leclair, 1962). In fact, as recalled by Hamilton (1991, 939-943), Veblen's influence on Herskovits and on Sahlins was crucial, while Malinowski's reciprocity theories became the backbone of the radical institutionalists' theory of value (Hamilton, 1965, 241).

Keynes believed that individual choices were the result of objective and subjective factors, derived from «those subjective and social incentives which determine how much is spent» (2008 [1936], 82). Thus it becomes impossible to analyse social behaviour as an aggregation of individual choices. He suggested therefore a consumer theory that stems from observable social behaviours and that allows for habits, rules and conventions to play a predominant role, in line with North American institutionalists. He even stated that «the strength of all these motives will vary enormously according to the institutions and organization of the economic society which we presume, according to habits formed by race, education, convention, religion and current morals, according to present hopes and past experience, according to the scale and technique of capital equipment, and according to the prevailing distribution of wealth and the established standards of life» (Keynes, 2008 [1936], 99).

The neo-institutionalist school is the one that stands out the most for its explicit rapprochement to anthropology, especially because it underscores the role played by social institutions. They centre the concept of value on the analysis of transaction costs, where an underlying neo-Ricardian objectivism can be detected. In this way, the transaction costs are added to the concept of production costs (which until now had only included the cost of capital productive factors,

\footnotetext{
${ }^{5}$ Morgan (1877) developed a three-stage system for the development of human society: savagery, barbarism and civilisation. Funnily enough, Veblen reached his conclusions after comparing capitalist society to primitive societies, both those that had been included in the «pacific barbarism» group and other primitive societies that were part of the next stage of «predatory barbarism» (Veblen, 1915 [1899]: 2-6).
} 
work and land). Transaction costs basically integrate the cost of use and the cost of information required in order to guarantee the exchange. The subject that values something does so because of the utility obtained through the good's different attributes, which must be measured. This implies that there is a cost for obtaining necessary information in order to make up for the asymmetry found in every relation of exchange. All these costs represent the rulemaking of rights and the institutionalisation of the idea of value, which can be identified as the «institutional framework». According to neoinstitutionalists, institutions guarantee and organise exchange, and determine transaction and processing costs. The institution's type of organisation and structuration depend of the simplicity or complexity of the society in question, from the more homogenous to the more heterogeneous type. Hence different models of exchange with an increasing multiplicity of attributes develop. North (1990) undertook a diachronic analysis of this process of institutionalisation. Firstly, he referred to the historically predominant type as a «personalised exchange» that is characterised by small-scale production and local trade and where no third party is needed in order to reach agreements. He then referred to «impersonal exchange», which is at the other extreme and does require complex institutions and the inclusion of a third party, large-scale production, far-away markets and impersonal or anonymous transactions.

Anthropologists had already highlighted the importance of social institutions in an economy's organisation, be it at a domestic level or a at a different-sized community level. Malinowski (1922), a classical anthropologist, had previously demonstrated how "primitive societies" institutionalised the value attributed to objects (be they sumptuous objects or staples), and how exchange had acquired the character of ritual ceremonies ${ }^{6}$. On the other hand, Hamilton (1965), a radical institutionalist, extended this application to modern societies, where the ceremonial aspect of reciprocal exchange is less important. The technological exchange of goods and services that results from the division of labour and the specialisation within our culture, goes hand in hand with a set of ceremonial financial exchanges that use money as a formal mechanism in order to authenticate exchange. Furthermore, both Ayres (1944) and his disciple Foster (1981) pointed out that the ritualization of the economy survives in current societies. They saw this as an evolutionary process of technological change, which is linked to value, and identified two functions in institutions: the instrumental function, used for the exchange of commodity and institutions, and the ceremonial function, used for the maintenance and consolidation of social statuses and power relations.

In Anthropology, the concept of value oscillates between theories that are based on social structure and organisation and theories that focus on behavioural aspects. Perry $(1930,490)$ distinguished two features in the concept of value. Firstly the value found in terms such as "good", "correct", and "what should be" implies decision-making and preference and loses its distinctive meaning due to common usage. Secondly, the value's feature lies in making a decision, as this implies that the meaning of value is reasonable, otherwise the demand is merely a subtle attempt to impose our desires on other people's options.

Graeber $(2001,2006)$ noted that there have been three main periods during which the idea of "value" was addressed. The first period was at the end of the 1950s, both in British social anthropology and in cultural anthropology from the United States of America. On the one hand, British structural-functionalism, headed by Radcliffe-Brown, addressed the idea of value from a systemic approach; society is seen as an organism with parts (institutions) that play a role in the maintenance of social order. On the other hand, in the United States of America Kluckhohn's works stand out, and they put forth a comparative study of the idea of value from an anthropological angle. He was based in New Mexico, where he tried to demonstrate that there were different systems of values in different social groups. Kluckhohn defined values such as «conceptions of the desirable», however, the desirable is not simply what people want, seen as desires are conditioned by the cultural context and, depending on each society, certain ideas prevail over others (success, harmony, purity, etc.). The problem lies in the comparison of a systemic way between these ideas, given the fact that their meaning and corresponding value terms are not the same. For this reason, Kluckhohn himself proposed a second less abstract level, known as «value orientations», linking it to human knowledge and thus implying that it is positive and desirable and avoids frustration and discomfort. At first, it seemed that these conceptions were more uniform, and therefore easier to compare, but Kluckhohn failed in his attempt.

Graeber placed the second stage in the early 1980s, when Anthropology was developing structuralist models and applied them to the idea of value. From this perspective, value was interpreted from within an abstract system of rules and meanings, and existed separate from any given act of expression. Value was thus reinterpreted from the perspective of people, elucidating its belonging to different identity groups, social classes etc. The argument surrounding the «theory of action» went well beyond classical structuralism, thus returning to the vision of market price as a good that is exchanged for another and regressing to economic theories on value following Appadurai (1986) and Thomas (1991). In

${ }^{6}$ In his famous ethnography on the Trobriand, Malinowski demonstrated how this society had managed to institutionalise economic exchanges; a payment in kind to the family and a kind of ceremonial gift prevailed (Kula). 
this context, Dumont (1982) argued that the notion of value is related to the concept of hierarchy, although he applied it to societies that are extremely hierarchized, such as the cast system in India. This is why Graeber argued that it was debatable whether or not it could be applied to modern market societies. Based on structural analysis, Dumont made a binary dichotomous correlation of concepts in order to establish «relations between relations», which in turn was criticised by Graeber for it does not take into account the process of implicit valuation in pairs, nor the fact that one may be superior to the other along with asymmetrical economic relations.

In the 1980s a new approach emerged, spearheaded by Marxist anthropology authors such as Turner (1979) and Munn (1986), whose phenomenological approach did not derive directly from Marx, but was based on the same dialectic tradition. This new approach was based on Marx's theory of value-work and the classical economists, but reinterpreted it by considering labour to be the equivalent of human creativity, and therefore, the value of things can be measured by the actions that derive from its acquisition. At no point did Marx postulate that the price that was paid for something gave a certain indication of its value. Graeber did take this approach and thus distanced himself from Marxist theory on labour, arguing that it is not possible to value labour from a market perspective in every society. In traditional market-less societies, value equals the actions it represents, while in market societies, money enables a symbolic representation of a product's real value, which is measured by proportionately comparing the work put into it to the market total.

According to Etzioni $(1988,101)$, value has two sources: pleasure and morality. On the one hand, there is a moral act that is underpinned by self-control, while on the other hand the streamlining of the commodities' utility builds on the removal of value judgements. In this way, Etzioni broke away from the traditional conception of a homo economicus who maximises utility, by stating that the selection process is not based on a one-dimensional model, but rather on a series of multidimensional complex situations that should be included, along with the regulatory and affective elements that have an impact on the way information is acquired and processed. When values are internalised they become part of an individual's perception, and when they are external, they act as restrictions in the decision-making process. Meanwhile, Frondizi (1963 [1958]) fell prey to the old debate on subjectivism and objectivism in terms of shaping value. He seemed to recognise the prevalence of subjectivism, he nonetheless considered objective qualities to be of importance, such as those related to the subject's reaction when facing these qualities, thus returning once again to the scholastics' intrinsic value. Castaingts (2002), however, saw value as a "cultural fact" that can be observed as a symbolic process, and pointed out that both subjectivism and objectivism do not take into account the symbolic character of value and valuation. Bourdieu (2010 [1979]) concurred with Veblen and linked the idea of value to social hierarchising, in such a way that individuals consider those commodities from the supposedly high classes as valuable. This is also linked to the notions of taste and distinction set by system that classifies values, lifestyles or habitus. Distinction does not only provoke a hierarchy in objects according to social classes and groups, but also allows for objects themselves to become the elements that hierarchise. This leads to possible conflicts and struggles for power.

\section{Conclusions}

Having reached this point, and having reviewed the economic and anthropological background, we find that it is essential to distinguish between the concepts of value and price, while maintaining an interrelated stance and multidisciplinary approach. Value is a symbolic interpretation, while price is the result of a negotiation between different parties. It is two sides of the same coin: on the one hand the qualitative and subjective perspective, and on the other the quantitative and objective measure. This dichotomous confrontation has been the underlying current of a sometimes-sterile debate between authors and schools, and the backbone of the resulting theories, as can be seen in our review.

In order to understand these concepts, it is essential to take the notion of "useful thing" as the starting point, i.e., those things that satisfy human needs. When referring to "needs" we must include both purely biological needs, that are vital for the individual's and the specie's survival, and cultural, social and psychological needs, in other words, all needs that lead to society's and its institutions' continuity. Different disciplines have addressed the issue of "needs", and in most cases sometimes-hierarchical classification systems have been established, according to what was considered a priority for life and social welfare. In Economics, Menger set up a classification system by distinguishing commodities linked to vital needs - i.e. primary needs - from other commodities. Similarly, other systems were put forward based on the degree of immediacy of those commodities at the time of providing satisfaction. Conversely, the classical anthropologist Malinowski pointed out cultural institutions arose according to two types of needs that wanted satisfying, and he classified them into two main groups: primary or biological (nutrition, reproduction, body care, safety, relaxation, movement and growth) and secondary human psychological needs. It is clear that the main problem surrounding theoretical visions, and more so, that conditions human action itself, lies in the fact that only some useful things are deemed to be economic commodities that are valuable or generate utility. 
We believe that today the traditional concept of "need" has been extended, and is no longer limited to physiological or social aspects, and to an individual and purely objective nature. There are other needs that people consider important, such as those related to pleasure, desire, taste, well being, joy and other subjective aspects and they do not always correspond to a practical or operational purpose, but in any case they help to prevent pain, frustration and discomfort. These needs are circumstantial, that is to say that they shift depending on the moment, place and historical context.

The concept of "need" is linked to that of "utility", i.e., to the ability that something has to be able to satisfy any type of need. The sphere of what is considered useful thus extends from the objective to the subjective and the individual to the social. We take up once again the theories developed by Nineteen Century utilitarians, from Bentham to the marginalists, who stated that "utility" is the ability something has to provide pleasure or prevent pain.

The useful object is considered a "commodity" if the following four conditions are met: the human need does actually exist, the useful object has a causal relationship with the need, the individual is aware of the existing causal relation, and lastly, there is the right to dispose of the object. In addition, those individuals who wish to satisfy their needs, estimate or calculate the required quantities, and clearly, these quantities may be higher or lower than the availability of commodities. Should the availability be low, compared to the commodities, the commodity is endowed with an economic nature or value. Conversely, commodities that are abundantly available are not economic commodities and have no value. The fact of not being available to satisfy needs may be due to environmental, social and/or legal constraints. Therefore, "commodities" are valuable "useful things" that are valued in proportion to their relative degree of availability and thus, value is not an intrinsic property of the commodity itself, but rather a continuously changing and shifting social construction, which can be consequently considered a universal and objective concept.

As a social construction, value is susceptible to being redefined in quantitative and proportional terms. There are subtle differences between "total utility" and "marginal utility" that go beyond the merely quantitative aspect; the preferential values that exponentially increase "total utility" are related to any given society's, social group's, sector's or class's conceptions on the desirable. For this reason "marginal utility" is always relative - it depends on the context and on the situation. It is also subjective for it depends on individual preferences. As a total social fact, value has been and is collectivised, and qualitative aspects are translated into quantitative aspects, i.e.an estimate based on expectations is assigned, and this may have to be corrected depending on the result. When one shifts from the individual to the collective level, these may be similar or almost identical. The fact that these coincidences take place, that a lot of people have the same expectation, is due to the influence of predominant cultural ideologies. Currently these can be marketing, advertising and other means. These collective coincidences in preferences are the so-called "use values", or simply, value.

By contrast, the "exchange value", i.e. the price, is related to the action of exchanging good and services, and this is defined as the quantity of a good received in exchange for another. Anthropology provides a transcultural vision to the idea of exchange, as the field does not limit itself to the "exchange value" while showing that the purpose is not always profit maximisation. Therefore, the "exchange value" is the result of an exchange that takes place in market societies, as it is possible to quote a price while a quantity and return time are established, at times in the shape of money. The price involves an exercise of rational valuation, but it does not always have to be balanced; this means that goods and services do not have to have the same value for two different subjects. However, establishing a price does imply there is an act of reflection, because different subjects undertake an exchange based on a reasoning that leads them to satisfy their needs according to their preferences. A negotiation process is established, enabling participating individuals to try and meet their expectations by finally reaching an agreement that is then reflected in the market price.

Due to the above reasons, we have verified how an economic science based on the analysis of individual behaviour motivated by a visible hedonism, slowly turns into a formal system that is stripped of any hint of subjectivism, to the point of expressing an excessive desire to imitate the positivism found in experimental sciences. In turn, heterodox currents emerge, and their hypotheses gradually become closer to the economic assumptions developed by economic anthropology. The separation between both sciences, referred to by Pearson $(2000,982)$ as a divorce, seems to be slowly but surely turning into a methodological and theoretical reconciliation, bestowing further realism on conclusions reached on economic models and their institutions and subsequently interpreting the economic world's complexity in its social and cultural environment.

\section{References}

Appadurai, A. (1986). The social life of things: Commodities in Cultural Perspective. Cambridge: Cambridge University Press.

Ayres, C. E. (1944). The Theory of Economic Progress. Chapel Hill: University of North Carolina Press.

Bourdieu, P. (2010) [1979]. Distinction: A Social Critique of the Judgement of Taste. Oxford: Routledge. 
Burling, R. (1962). Maximization theories on the study of economic Anthropology. American Anthropologist, 64, 4, 802-821.

Cantillon, R. (1959) [1775]. Essais sur la nature du commerce en general (Essay on the Nature of Trade in General). London: Frank Cass and Company Ltd.

Castaingts, J. (2002). Simbolismos del dinero. Antropología y economía: una encrucijada. (Symbolism of money). Barcelona-Iztapalapa: Anthropos Editorial.

Coase, R.H. (1960). The Problem of Social Cost. Journal of Law and Economics, 3, 1-44.

Debreu, G. (1959). Theory of Value. An Axiomatic Analysis of Economic Equilibrium, Nueva York: John Wiley \& Sons.

Dobb, M. (1937). Political Economy and Capitalism: Some essays in economic tradition. Londres: George Routledge \& Sons, Ltd.

Dumont, L. (1982). On value. Proceedings of the British Academy, 66, 207-241.

Edgeworth, F. Y. (1881). Mathematical Psychics. An Essay on the application of mathematics to moral sciences, Londres: C. Kegan Paul \& $\mathrm{C} 0$.

Etzioni, A. (1988). The moral dimension. Toward a new economics. New York: The Free Press.

Fisher, I. (2007) [1892]. Mathematical Investigations in the Theory of Value and Prices. Nueva York: Cosimo Inc.

Foster, J. F. (1981). The Relation between the Theory of Value and Economic Analysis. Journal of Economic Issues, 15, 4, $899-905$.

Frondizi, Risieri, (1963) [1958]. What is value? LaSalle, Illinois: Open Court Publishing Company.

Graeber, D. (2001). Toward an anthropological theory of value. New York: Palgrave.

Graeber, D. (2006). Value: Anthropological Theories of Value. In J. G. Carrier (Ed.), A Handbook of Economic Anthropology (pp. 439454). Northampton: Edward Elgar Publishing.

Gregory, C. A. (1997). Savage Money: The Anthropology and Politics of Commodity Ex-change. Amsterdam: Harwood Academic Publishers.

Hamilton, D. (1965). The great wheel of wealth. A reflection of social reciprocity. Journal of Economics and Sociology, 24, $241-248$.

Hamilton, D. (1991). The Meaning of Anthropology for Economic Science: A Case for Intellectual Reciprocity. Journal of Economic Issues, 25, 4, 937-949.

Herskovits, M. J. (1952). Economic Anthropology. A Study in comparative economics. New York: Alfred A. Knopf.

Hicks, J. R. y Allen, R. G. D. (1934). A Reconsideration of the Theory of Value. Part I. Economica, 1, 1, 52-76.

Jevons, W. S. (1871). The Theory of political Economy. Londres: McMillan \& Co.

Keynes, J. M. (2008) [1936]. General Theory of Employment, Interest and Money. New Delhi: Atlantic Ltd.

Kluckhohn, C. (1951). Values and Value-Orientations in the Theory of Action. An Exploration in Definition and Classification. In T. Parsons, and E. A. Shils (Eds.), Toward a General Theory of Action (pp. 388-433). Cambridge: Cambridge University Press.

Knight, F. H. (1941). Anthropology and Economics. Journal of Political Economy, 49, 247-268.

Lancaster, K. J. (1966). A New Approach to Consumer Theory. Journal of Political Economy, LXXIV, 2, 132-157.

LeClair, E. E. (1962). Economic Threory and Economic Anthropology. American Anthropologist, 64, 6, 1179-1203.

Majumdar, T., (1958). The measurement of utility. Nueva York: St. Martin's Press, Inc.

Malinowski, B. (1922). Argonauts of the Western Pacific. London: Routledge.

Malthus, T.R., (1836) [1820]. Principles of political economy considered with a view to their practical application. London: William Pickering.

Marshall, A. (1890). Principles of economics. London: Macmillan and Co.

Marx, Karl, (2007) [1867]. Capital: a critique of political economy, Vol. I. New York: Cosimo, Inc.

Menger, C. (2007) [1871]. Principles of economics Auburn (Ala.): Ludwig von Misses Institute.

Mill, John S., (1870) [1848]. Principles of Political Economy: With Some of Their Applications to social philosophy. New York: D. Appleton and Company.

Mises, L. von, (1963) [1949]. Human Action: A Treatise on Economics. San Francisco: Fox \& Wilkes.

Mishan, E. J. (1961). Theories of Consumer's Behaviour: A Cynical View. Economica, 28, 109, 1-11.

Mitchell, W. (1914). Human Behavior and Economics: a survey of recent literature. Quarterly Journal of Economics, $29,1,1-47$.

Morgan, L. H. (1877). Ancient Society. Nueva York: Henry Holt \& Co.

Munn, N. D. (1986). The fame of Gawa. Cambridge: MA, Cambridge University Press,

North, D. (1990). Institutions, Institutional Change and Economic Perfomance. Cambridge: Cambridge University Press.

Pareto, W. (1971) [1906]. Manual of political economic. New Jersey: Scholars Book Shelf.

Pearson, H. (2000). Homo Economicus. Goes Native, 1859-1945: The Rise and Fall of primitive Economics. History of Political Economy, 32, 4, 933-989.

Perry C. M. (1930). Value as any object of any interest. International Journal of Ethics, Vol. 40, 4, 490-495.

Pigou, A. C. (1912). Wealth and Welfare, Londres: Macmillan.

Ricardo, David, (1821). On the Principles of Political Economy and Taxation. London: John Murray.

Samuelson, P. A. (1938). A Note on the Pure Theory of Consumer's Behaviour. Economica, 5 (17), 61-71.

Say, J. B., (1826). Traité d'économie politique ou simple exposition de la maniére dont se forment, se distribuent et se consomment les richesses (5rd. ed.) (A Treatise on Political Economy; Or, The Production, Distribution, and Consumption of Wealth). Paris: Guillaumin, Libraire.

Sen, A. (2003). Sraffa, Wittgenstein, and Gramsci, Journal of Economic Literature, 41, 4, 1240-1255.

Smith, Adam, (1904) [1776]. An Inquiry into the nature and causes of the wealth of nations. Vol. I, London: Methuen and Co.

Stigler, G. J. (1972). The Adoption of the Marginal Utility Theory. History of Politica Economy, 4, 2, 571-586. 
Thomas, N. (1991). Entangled objects: exchange material culture, and colonialism in the Pacific. Cambridge, MA: Harvard University Press.

Turner, T. (1979). Anthropology and the politics of indigenous peoples' struggles. Anthropology, 5, 1-43.

Veblen, T. (1909). The Limitations of Marginal Utility. Journal of Political Economy, 17, 9, 620-636.

Veblen, T. (1915) [1899]. The Theory of Leisure Class: An Economic Study of Institutions. New York: Macmillan.

Walras, L. (1977) [1874]. Elements of Pure Economics or the Theory of Social Wealth, Fairfield: Augustus M. Kelley Publishers. 